\title{
Revista Facultad de Ingeniería
}

Journal Homepage: https://revistas.uptc.edu.co/index.php/ingenieria

\section{Systematic Mapping of the Harmonization of SCRUM and ISO 9001}

\author{
Darly-Liliana Burbano-Delgado ${ }^{1}$ \\ César-Jesús Pardo-Calvache ${ }^{2}$ \\ Carlos-Eduardo Orozco-Garcés ${ }^{3}$
}

Received: April 12, 2021

Accepted: May 13, 2021

Published: May 24, 2021

Citation: D.-L. Burbano-Delgado, C.-J. Pardo-Calvache, C.-E. Orozco-Garcés, "Systematic Mapping of the Harmonization of SCRUM and ISO 9001," Revista Facultad de Ingeniería, vol. 30 (56), e13303, 2021. https://doi.org/10.19053/01211129.v30.n56.2021.13303

\section{Abstract}

Small and medium-sized companies have limitations related to the amount of human talent and capital they have, which causes their processes to be disorganized and affects the quality of the products or services they offer. To address this problem, several solutions that allow companies to improve their processes and the way their projects are managed have appeared, some of the most common in the software industry are Scrum and the ISO 9001 standard or its Latin American variants (NTC 6001, NTG 66006 and NTE INEN 2537). In this sense, the objective of this article is

\footnotetext{
1 Universidad del Cauca (Popayán-Cauca, Colombia). darlybur@unicauca.edu.co. ORCID: 0000-0003-37919742

${ }^{2}$ Ph. D. Universidad del Cauca (Popayán-Cauca, Colombia). cpardo@unicauca.edu.co. ORCID: 0000-00026907-2905

${ }_{3}^{3}$ M. Sc. (c) Universidad del Cauca (Popayán-Cauca, Colombia). corozco@unicauca.edu.co. ORCID: 00000003-3791-9742
} 
to present the results obtained after carrying out a systematic mapping of the literature to identify proposals and related studies. Although it was possible to identify some related studies, the topic has great relevance for the software industry given the benefits that would be enabled in an integrated manner by implementing a quality management system based on the specifications of the ISO standard together with the agile approach Scrum. In conclusion, it was possible to observe that, although there are differences between the ISO and Scrum standards, they are not incompatible, on the contrary, they turn out to be complementary.

Keywords: harmonization of multiple models; ISO 9001; NTC 6001; NTE INEN 2537; NTG 66006.

\section{Mapeo sistemático sobre la armonización de Scrum y la norma ISO 9001}

\section{Resumen}

Las micro, pequeñas y medianas empresas cuentan con limitaciones relacionadas con la cantidad de talento humano y capital que poseen, lo cual ocasiona que sus procesos sean desorganizados y la calidad de los productos y/o servicios que ofrecen se vea afectada. Para abordar esta problemática, han aparecido algunas soluciones que permiten mejorar sus procesos y la manera como se gestionan sus proyectos, algunos de los más utilizados por la industria se software son: Scrum y la norma ISO 9001 o sus variantes latinoamericanas como NTC 6001, NTG 66006 y NTE INEN 2537. En este sentido, este artículo presenta los resultados obtenidos tras realizar un mapeo sistemático de la literatura con el objetivo de identificar propuestas y estudios relacionados en el área. Aunque fue posible identificar pocos estudios relacionados, el tema es de relevancia para la industria de software dado los beneficios de los cuales se dispondría de manera integrada al implementar un sistema de gestión de la calidad a partir de las especificaciones de la norma ISO junto con el enfoque ágil Scrum. En conclusión, fue posible observar que, aunque existen diferencias entre las normas ISO y Scrum, estas no son incompatibles, al contrario, resultan ser complementarias.

Palabras claves: armonización de múltiples modelos; ISO 9001; NTC 6001; NTE INEN 2537; NTG 66006. 


\section{Mapeamento sistemático na harmonização de Scrum e ISO 9001}

\section{Resumo}

As micro, pequenas e médias empresas apresentam limitações relacionadas à quantidade de talento humano e capital que possuem, o que desorganiza seus processos e prejudica a qualidade dos produtos e / ou serviços que oferecem. Para resolver este problema, surgiram algumas soluções que permitem melhorar seus processos e a forma como seus projetos são gerenciados, algumas das mais utilizadas pela indústria de software são: Scrum e o padrão ISO 9001 ou suas variantes latino-Americano como o NTC 6001, NTG 66006 e NTE INEN 2537. Nesse sentido, este artigo apresenta os resultados obtidos após a realização de um mapeamento sistemático da literatura a fim de identificar propostas e estudos relacionados na área. Embora tenha sido possível identificar poucos estudos relacionados, o tema é de relevância para a indústria de software pelos benefícios que estariam disponíveis de forma integrada na implantação de um sistema de gestão da qualidade baseado nas especificações do padrão ISO em conjunto com a abordagem Ágil Scrum. Em conclusão, foi possível observar que, embora existam diferenças entre os padrões ISO e Scrum, eles não são incompatíveis, pelo contrário, acabam se tornando complementares.

Palavras claves: armonizacion de múltiplos modelos; ISO 9001; NTC 6001; NTE INEN 2537; NTG 66006. 


\section{INTRODUCTION}

According to the Superintendency of Societies and the Colombian Federation of Software Industry and Information Technologies (FEDESOFT), 85\% of the software development companies in Colombia are very small entities (VSEs) [1]. The software industry is perceived as an opportunity to promote competitiveness and economic growth because it currently contributes with $1.5 \%$ of the annual Gross Domestic Product (GDP) [2] and employs more than 100000 people [3]. Additionally, VSEs are characterized by aspects such as: (i) lack of human talent, (ii) limited amount of capital and (iii) limited capacity to adopt models and solutions to manage their internal processes; which results in the application of poorly organized processes and the degradation of the quality of the products or services offered to the market [4]. However, software companies can choose to adopt and apply models that allow them to improve the quality of their processes. Nevertheless, achieving this requires investing a considerable amount of money, effort and time in aspects such as: (i) improvement of existing processes, (ii) training of new human talent, (iii) adoption of new models, (iv) certifications, ( $v$ ) audits and specialized consultancies, among others [5].

As a result, it is possible that most VSEs do not have the resources to adopt expensive solutions. In this sense, VSEs decide to carry out the implementation of agile approaches, frameworks and models (agile solutions) such as: Scrum [6], Extreme Programming (XP) [7], Lean practices [8], among others. According to the annual report of agility state [9], a large number of companies on the market apply Scrum (58\%), Scrumban (10\%), Kanban [10] (7\%), the iterative and incremental model [11] (4\%), XP [7] (1\%) and Lean Startup [12] (1\%). On the other hand, 9\% of companies apply hybrid models and $3 \%$ of companies do not apply models or do so empirically. In addition, agile approaches provide different advantages over traditional ones, including: (i) less document load, (ii) greater flexibility and efficiency in highly demanding development environments, (iii) focus on constantly adding value to the business, (iv) greater tolerance to change management, (v) include the client in their processes, (vi) establish mechanisms and strategies for continuous 
improvement, among others $[13,14]$. Likewise, the use of agile solutions allows to create self-organized and collaborative teams with better communication [15, 16]. However, agile approaches face different challenges that must be managed properly to avoid business losses [17], for example: (i) the lack of skills in work teams [18] and (ii) the lack of experience with the approaches by the team members. Less or no management of these challenges can incur on rework, delays in scheduled deliveries and constant uncontrolled changes, compromising critical aspects such as: scope, quality, cost and time [19]. Therefore, it is possible to observe that the methodologies and frameworks are not enough to offer quality products or services, making necessary the use of solutions that allow to manage the internal quality of their processes, with the aim of establishing the criteria and necessary elements for a company to be competitive, innovative, comprehensive and sustainable [13]. To achieve this, solutions such as the ISO 9001 standard [20] have been defined, which establishes the elements that companies must define to carry out the management of their internal processes. Additionally, lighter, and less expensive adaptations of the ISO 9001 standard have been defined with the aim of proposing solutions focused on VSEs, among them: the NTC 6001 standard (Colombia) [21], the NTG 66006 standard (Guatemala) [22] and the NTE INEN 2537 standard (Ecuador) [23], which are applied in accordance with the regulations and policies established by each country.

In this sense, the objective of the systematic mapping of the literature (SML) presented in this paper focuses on identifying studies and efforts related to the integration or harmonization (action so that two or more models are compatible and do not have differences between their characteristics) of Scrum [6], which is one of the most used agile approaches in the software industry, with the ISO 9001:2015 standard or its adaptations in Latin America (NTC 6001, NTG 66006 and NTE INEN 2537). After analyzing the results, it was possible to identify that some efforts have been made to harmonize Scrum with the ISO 9001:2015 standard. However, no related studies focusing on the use of adapted versions of the standard were identified. On the other hand, efforts aimed at diagnosing the level of implementation of the standard in software development companies were identified. 
The document is organized as follows: section 2 describes the research protocol used to perform the SML. Section 3 presents the results. Section 4 presents the discussion of the results, some observations and limitations identified in the field of interest. Finally, in Section 5 the conclusions and future work are presented.

\section{MEthodology}

The SML is a classification scheme that helps to structure and categorize the knowledge associate with a field of interest. This SML was carried out following the protocol proposed in [24] and [25], applying the following stages: (i) planning, (ii) execution and (iii) documentation.

\section{A. Planning Stage}

The activities associated to this phase were: (i) definition of the research questions following the objectives of the study, (ii) execute the research applying the research query, (iii) selection of articles for inclusion and exclusion, (iv) extraction of keywords from abstracts and $(\mathrm{v})$ extraction of data and mapping process. The figure of the process can be consulted at: https://bit.ly/3AJKTRg.

1) Objectives and research questions. The set of research questions was established following the Goal-Question-Metrics methodology (GQM) [26]. This approach suggests a measurement model composed of three levels of abstraction: (i) conceptual level (Objective), (ii) operational level (Question) and (iii) quantitative level (Metric). At a conceptual level, the research questions that are aligned with the objectives were designed, these questions allowed to focus, characterize, and structure the information related to the area of interest.

Considering the above, a general objective and a set of specific objectives were proposed, due to space limitations, both the general and the specific objectives can be consulted at https://bit.ly/3iMMvTO. At https://bit.ly/3siJHkt the research questions $(R Q)$, their motivation and related objective are presented. The motivation of the questions allows to improve the objectivity in the application of the questions to each of the articles. 
2) Research Strategy. The search query was designed by applying logical AND/OR connectors. The research query was: ("agile approaches" OR "agile methodologies") AND ("NTC 6001" OR "ISO 9001" OR "NTG 66006" OR "NTE 2537"). It was composed as follows: "agile approaches" OR "agile methodologies", which allows to identify the studies related to agile approaches ("NTC 6001" OR "ISO 9001" OR "NTG 66006" OR "NTE 2537") including the international standard ISO 9001 and the Latin American variants (NTC 6001, NTG 66006 and NTE INEN 2537). The research was carried out in the following scientific databases: Google Scholar, IEEEXplore, Scopus, ScienceDirect and SpringerLink. In addition, the research included publications in the interval between 2015 and 2021 because the research interest was based on the updates and adaptations of the ISO 9001:2015 standard. The adaptations of the query can be consulted at: https://bit.ly/2Xrbbt4.

3) Inclusion/Exclusion Criteria. The article collection and classification processes were based on three review stages, as the first selection scheme. The titles of the articles were considered, followed by a review of the abstract, introduction and conclusions to decide if the article should be included as a relevant study. In addition, the articles classified as relevant were evaluated using a set of inclusion and exclusion criteria that can be consulted at https://bit.ly/2Xw34eV. Moreover, the references of each article were not evaluated. The backward and forward snowballing effects were not considered.

4) Quality Evaluation Criteria. The quality of the primary studies was evaluated by means of a questionnaire with a scoring system of 3 values $(-1,0 y+1)$. the questionnaire, score and quality evaluation criteria can be consulted at https://bit.ly/2VSkyRE.

5) Execution Stage. The process implemented to obtain the results of the SML is presented at https://bit.ly/3sgkneW. After applying the refinement filters, it was possible to reduce from an initial search without filters with a total of 919 to 79 articles of which 5 remained as primary studies, the rest were eliminated because they did not match the inclusion and exclusion criteria. The process results of applying the mapping filters are presented at https://bit.ly/3sgkneW. 


\section{RESULtS}

In this section, an answer to each of the research questions is given (see https://bit.ly/3siJHkt) the studies are referenced to facilitate in-depth analysis by the reader.

\section{A. Which Articles Were Found and How Many Cover the Investigated Topics? What is the Distribution in Time of the Selected Primary Studies?}

The total of relevant articles found was 79 , which were grouped by search engine and the percentage they represent in relation to the total number of retrieved articles. The result was obtained after applying the following filters: (i) delimitation of time window from 2015 to 2021 (ii) search only articles, technical reports and gray literature that describe facts based on the experience or the observation and (iii) include works on English and Spanish languages. From the group of relevant articles only $5(6.33 \%)$ were selected as primaries, the remaining 74 studies $(93.67 \%)$ were not aligned with the mapping objectives and were excluded.

According to the time distribution: 2 articles ([28, 29]) (40\%) were published in 2018, and the years 2017, 2019 and 2020 report 1 article ([30,31, 32]) $(60 \%)$, respectively. At https://bit.ly/2VWIVy3 you can see the distribution in time of the articles.

\section{B. What is the Local Distribution of Primary Studies? What is the Geographical Distribution of the Selected Primary Studies?}

From the analysis of the articles, it could be observed that there are 2 studies published in scientific events: the XXIV Argentine Congress of Computer Sciences [28] (20\%) and the Software and Knowledge Engineering Iberoamerican Journals 2020 [32] (20\%) (papers). In addition, studies were identified in the digital repository of the North Technical University [29] (20\%), The Nueva Granada University digital repository [30] (20\%) and La Plata National University institutional repository [31] (20\%) (monographs). Likewise, it can be observed that: 2 studies ([28, 32]) (40\%) were published in Colombia, 2 studies ([31, 30]) (40\%) were published in Argentina and 1 study ([29]) (20\%) was published in Ecuador. The distribution of the articles can be observed at https://bit.ly/3xOOmvl. 


\section{Which Primary Studies Have Been the Most Cited?}

From the analysis of the results, the following was observed: [28] is the most cited article (4 citations); on the other hand, ([29, 30, 32, 31]) have not been cited by other authors, probably because the related studies were recently published.

\section{According to What Type of Research are the Studies Classified [27]?}

According to the classification of the research types proposed in [27], these can be of 6 types: (i) validation research; (ii) evaluation research; (iii) proposed solution; (iv) philosophical articles; (v) opinion articles and (vi) experience articles, the definition of each type can be consulted in detail at https://bit.ly/3iKuWUz. After classifying the primary studies, it was found that they were only classified in 2 types: evaluation research ([30]) (20\%) and proposed solution ([28, 29, 32, 31]) $(80 \%)$.

\section{E. Which Evaluation Methods Tend to be the Most Applied? What is the Quality}

\section{Level of the Selected Studies?}

It was observed that the most used evaluation methods are case studies ([29, 32]) $(40 \%)$, the remaining studies $([30,31,28])(60 \%)$ do not apply any kind of evaluation method. Besides, according to the quality evaluation criteria, the following scores were observed: [32] ( 6 points), follow by [28] (3 points), [31] (3 points), [29] (2 points) and [30] (0 points). However, [30] was included because it makes interesting contributions related to the diagnosis of the degree of compliance with the requirements associated with the ISO 9001 standard. The application of the criteria for the quality evaluation can be consulted at https://bit.ly/3Ayitxw.

\section{F. What Kind of Solutions are Proposed?}

In [29] the development of a software application and its evaluation is carried out to manage the standardization of the processes based on the ISO 9001 standard within a company. In [32] the harmonization between the ISO 9001 standard and Scrum it is proposed to allow VSEs to implement a lighter process for quality management, the proposal was validated through a case study applied in a software company. In 
[30], a diagnostic report of a company is presented, which seeks to define the level of implementation of a Quality Management System (QMS) under the parameters established by the ISO 9001:2015 standard. It was possible to observe that the percentage of implementation obtained by the company was $25 \%$, which was determined by comparing the processes defined by the company with those required within the standard. In [28] the application of a proposal to integrate the documentation used by Scrum and the ISO 9001:2015 standard was carried out, this integration aimed to define the necessary documentation to satisfy the analysis, requirement and planning stages defined by a company. The application of the proposal was carried out in the Software Engineering II course dictated in the computer science department of the La Plata National University. Finally, in [31] an implementation of the ISO 9001:2015 standard was proposed. However, the authors do not present a validation of their proposal.

\section{G. Which Results Were Obtained at the Conclusion of the Research Process?} What is the Inclination That the Research Topic Has Taken in the Last Six Years?

From the analysis of the results, it was observed that few studies have been proposed in relation to the harmonization between Scrum and the ISO 9001:2015 standard. However, it was identified that the existing solutions share some common elements, such as: customer satisfaction and team members relationship management, which opens an interesting gap for possible harmonization. In addition, it was observed that: 3 studies $([32,31,28])(60 \%)$ propose a type of integration or guide between the ISO 9001: 2015 standard and Scrum. In the remaining $40 \%$ of the literature, it can be observed that: 1 study ([30]) (20\%) carried out a diagnosis of the level of implementation of the QMS and 1 study ([29]) (20\%) presents a software tool to support the ISO 9001:2015 standard process management. 


\section{H. Which Future Works Can Be Identified from the Studies Analyzed?}

Among the most relevant future work, it can be noticed the implementation of a software tool that allows managing or keeping track of the different elements of the harmonization process between Scrum and the NTC 6001 standard [32]. For example, as they are fulfilling the different points in the realization of the harmonization, it is also possible to implement the application of the proposal in different contexts and projects to verify its effectiveness by validating aspects such as: (i) time, (ii) process improvement, (iii) human talent demand and (iv) use of consultancies. Besides, it is also suggested to work on an initiative that defines the necessary documentation, for those who use the proposal defined in [31], through templates to support the harmonization process for each particular company. Also, the possibility of conducting an experimental study [32] to allow the verification of effectiveness of different harmonization proposals its suggested with the aim of comparing different approaches from a theoretical and practical point of view.

\section{Discussion}

This section presents the analysis of the results obtained in the execution of the SML.

\section{A. Main Observations}

It was noted that all the literature was focused on the ISO 9001:2015 standard. However, the SML was also directed to its adaptations (NTC 6001 standard, NTG 66006 standard and NTE INEN 2537 standard), which are focused and designed for its application in VSEs, with the aim of adopting a solid management model that allows reaching high levels of quality and competitiveness in the industry. Likewise, after carrying out the process of analyzing the related primary studies and classifying them by country, it was identified that all the research production is from Latin America. In addition, based on the indexes of academic search engines, it was evidenced that most of the studies have not been cited. Finally, it was observed that 3 studies ([28, 32, 31]) (60\%) propose integration guides between Scrum and the 
ISO 9001:2015 standard; 1 study ([30]) (20\%) contributes to the research with ideas and factors to consider in order to define the viability of the adoption of standards by software companies, and 1 study ([29]) (20\%) proposes a software application that allows to control the processes applied to the definition and implementation of the companies standards.

\section{B. Limitations}

The limitation to academic search engines represents the state of the art related to the harmonization between Scrum and the ISO 9001:2015 standard or its adaptations (NTC 6001 standard, NTG 66006 standard and NTE INEN 2537 standard). The inclusion of studies only in English and Spanish may exclude relevant studies published in other languages. Finally, although this SML has yielded few primary results, these serve as a starting point for a later version of the systematic mapping.

\section{Transcendence for Research and Practice}

The SML observations have great significance for those researchers who are planning to investigate the harmonization of Scrum and the ISO 9001:2015 standard or its adaptations. For researchers, VSEs and consultants it is an area of interest because it can support the implementation of QMS in VSEs, in addition to integrating project management practices through Scrum, which is one of the agile approaches with greater implementation in the software industry. Besides, the SML will allow researchers and stakeholders to carry out the definition of guides to improve the way in which Scrum and the ISO 9001:2015 standard can be harmonized. Finally, organizations will benefit from the advancement of this field, since, so far, many software VSEs have not defined a QMS that allows them to be competitive, innovate, durable and comprehensive, whit a solid internal structure and high standards. In addition, companies will be more agile, tolerant to change and with the ability to quickly deliver value in their projects. 


\section{CONCLUSIONS}

The SML allowed the identification of works related to the definition of proposals that seek to harmonize Scrum and the ISO 9001:2015 standard or its adaptations. From the results obtained, it could be possible to identify an interest on supporting the use of agile approaches to improve the process management in software companies. On the other hand, it should be noted that, although there are differences between the ISO standard and Scrum, they are not incompatible, on the contrary they turn out to be complementary.

Regarding future work, it was possible to identify the following gaps: (i) the harmonization of the elements proposed by the Colombian NTC 6001 standard and Scrum from the harmonization carried out in [32] (ii) sharing the harmonization in a website that allows other researchers and companies to access the results obtained in the previous point and (iii) the implementation of a software application that allows to manage or keep track of the different issues related to the harmonization process between Scrum and the Colombian NTC 6001 standard.

\section{ACKNOWLEDGEMENT}

Likewise, we thank the company SITIS SAS, which has provided financial support so that the results of this project are visible.

\section{AUTHOR'S CONTRIBUTION}

Darly-Liliana Burbano-Delgado: Investigation, Formal Analysis, Methodology, Writing.

César-Jesús Pardo-Calvache: Supervision, Methodology, Validation, WritingRevision and Edition.

Carlos-Eduardo Orozco-Garcés: Supervision, Methodology, Validation, WritingRevision and Edition.

\section{References}

[1] C. A. García, "Software colombiano va por $5 \%$ del PIB: Fedesoft," El Tiempo, 22, Nov, 2020. https://bit.ly/2VCtWc 
Systematic Mapping of the Harmonization of SCRUM and ISO

[2] MinTic, EI MinTIC y Fedesoft firmaron un acuerdo para contribuir al crecimiento de las empresas del sector TI, MinTic, Bogotá D.C., Colombia, 2020. https://bit.ly/3A8tWQw

[3] L. E. P. Valencia, L. C. Benjumea, A. T. Lazo, "Estado del arte que soporta el proceso de desarrollo de software en las PYMES colombianas: Una mirada desde las organizaciones nacionales que tienen que ver con la disciplina," Entre Ciencia E Ingeniería, vol. 5, no. 10, pp. 93-107, 2012.

[4] L. N. Elola, N. G. Casarejos, M. J. V Jimenez, "El panorama actual de las pymes: ventajas y desventajas competitivas", Esic Market, vol. 107, no. 1, pp. 161-178, 1999.

[5] UBF, "Ventajas y desventajas de las metodologías Agile (ágiles)," ebf.com.es, 2019. https://bit.ly/3rvlu8L

[6] K. Schwaber, J. Sutherland, The Scrum Guide, Scrum guides, New York, USA, 2020.

[7] K. Beck, Extreme Programming Explained: Embrace Change. Boston: Addison-Wesley, 2010.

[8] J. Little, Lean Change Management: Prácticas Innovadoras Para El Manejo del Cambio Organizacional. The Netherlands: Happy Melly Express, 2014.

[9] Digita.ai, "14th Annual State of Agile Report," State of Agile, 2020. https://bit.ly/3fn57IQ

[10] J. Edge, Kanban: The Ultimate Guide to Kanban Methodology for Agile Software Development. New York, USA: Bravex Publications, 2018.

[11] Agiles.org, Desarrollo iterativo e incremental, 2020. https://bit.ly/3frWrR1

[12] F. J. L. Fernández, J. C. F. Rodríguez, "La metodología Lean Startup: desarrollo y aplicación para el emprendimiento," Revista Escuela de Administración y Negocios, no. 84, pp. 79-95, 2018. https://doi.org/10.21158/01208160.n84.2018.1918

[13] E. Europea, ¿Qué beneficios se pueden obtener al implementar la norma ISO 9001?, 2018. https://bit.ly/3u5LvNp

[14] M. Trigas, Desarrollo detallado de la fase de aprobacion de un proyecto informatico mediente uso de metodologias ágiles. New York, USA: Bravex Publications, 2015.

[15] J. R. Fuentes, Desarrollo de Software Ágil: Extreme Programming y Scrum. Southport, UK: CreateSpace Independent Publishing Platform, 2015.

[16] H. Kniberg, M. Skarin, Kanban and Scrum: making the most of both. New York, USA: C4Media, 2010.

[17] A. Perez, "Las 11 trampas de la metodología Scrum," OBS Business School, 2016. https://bit.ly/3wa14Wa

[18] J. H. A. Londoño, Las habilidades blandas -Soft Skills- de un Scrum Master, 2017. https://bit.ly/31uVwHX

[19] R. C. Gonzalez, El difícil problema de la estimación, 2007. https://bit.ly/3ru8z6X

[20] I. T. Excellence, ISO 9001 - Software ISO 9001 de Sistemas de Gestión ISO, 2018. https://bit.ly/34pjwgZ

[21] ICONTEC, Certificación NTC 6001, Modelo de Gestión para la pequeña y mediana empresa," 2019. https://bit.ly/3yJh9DA

[22] Coguanor, "COGUANOR NTG 66 006," Comision Guatemalteca de Normas Ministerio de Economía, Guatemala, EI Salvador, Tech. Report. ICS: 03.1250.10, 2010.

[23] Inen, "Norma técnica ecuatoriana NTE INEN 2537:2010," $1^{\text {st }}$ ed., Ecuador: Instituto ecuatoriano de Normalización, Quito, Ecuador, Tech. Report. FB 13.04-401, 2010.

[24] K. Petersen, R. Feldt, S. Mujtaba, M. Mattsson, "Systematic mapping studies in software engineering," in 12th International Conference on Evaluation and Assessment in Software Engineering, pp. 68-77, Jun. 2008. https://doi.org/10.14236/ewic/ease2008.8

[25] K. Petersen, S. Vakkalanka, L. Kuzniarz, "Guidelines for conducting systematic mapping studies in software engineering: An update," Information and Software Technology, vol. 64, pp. 1-18, 2015. https://doi.org/: 10.1016/j.infsof.2015.03.007

Revista Facultad de Ingeniería (Rev. Fac. Ing.) Vol. 30 (56), e13303, April-June 2021. Tunja-Boyacá, Colombia. L-ISSN: 0121-1129, e-ISSN: 2357-5328.

DOI: https://doi.org/10.19053/01211129.v30.n56.2021.13303 
[26] V. Basili, Software Modeling and Measurement: The Goal/Question/Metric Paradigm, University of Maryland at College Park, Maryland, United States, Tech. Report. CS-TR-2956, Sep 1992.

[27] R. Wieringa, N. Maiden, N. Mead, C. Rolland, "Requirements engineering paper classification and evaluation criteria: A proposal and a discussion," Requirements Engineering, vol. 11, pp. 102-107, 2006. https://doi.org/10.1007/s00766-005-0021-6

[28] J. Calabrese, S. Esponda, M. Boracchia, P. Pesado, "Hacia una mejora de calidad en Scrum: integrando documentación requerida por IRAM-ISO 9001:2015," in XXIV Congreso Argentino de Ciencias de la Computación, La Plata, Argentina, 2018, pp. 662-671.

[29] J. Arellano, C. Paola, "Desarrollo de un Software para la Gestión por Procesos, basada en la ISO 9001:2015 para la Dirección de Tecnología de la Información de la empresa Eléctrica Regional Norte "EMELNORTE S.A.", Grade Thesis, Universidad Técnica del Norte, Colombia, 2018.

[30] N. E. Ruiz, "Diagnóstico inicial para la implementación de la norma ISO 9001:2015 en Remarq S.A.S", Grade Thesis, Universidad Militar Nueva Granada, Bogotá D.C., Colombia, 2017.

[31] M. F. Burdino, C. Salgado, M. Peralta, A. Sanches, A. R. Mendarozqueta, Guía para la aplicación de la norma ISO 9001:2015 en el desarrollo ágil de software, Universidad Nacional de La Plata, La Plata, Argentina, 2019.

[32] C. Pardo, M. Morcillo, E. Suescún, "Estrategia para la homogeneización, comparación e integración de Scrum e ISO 9001: 2015," Revista Ibérica de Sistemas y Tecnologías de la Información, no. E38, pp. 5874, 2020. 